\title{
Measuring the performance of poultry business through effective supply chain management skills
}

\author{
Reza Ronaldo ${ }^{\mathbf{a}^{*}}$
}

${ }^{a}$ Lecturer of STEBI Lampung University, Indonesia

\begin{tabular}{l}
\hline C H R O N I C L E \\
\hline Article history: \\
Received July 16, 2019 \\
Received in revised format July \\
30,2019 \\
Accepted August 112019 \\
Available online \\
August 112019 \\
\hline Keywords: \\
Supplier involvement \\
Integrator involvement in Poultry \\
Product modularity \\
SCM skills \\
Poultry product business \\
performance
\end{tabular}

\section{Introduction}

For the last thirty years, production in livestock has grown worldwide. Economists agree that the demand of livestock has increased due to the increase in population and higher economic growth Delgado et al. (2020), With regard to contracts, the economic linkages between companies and those in the poultry farming industry have also increased exceptionally in the last twenty years. Research studies on poultry farming in Asia and Africa (Williams et al., 2017) illustrate the growth of poultry in the last two decades, McKenzie et al. (2018) examine the contract relationships between the poultry growers and suppliers which has resulted in an incredible growth of poultry production and increase in the performance of poultry business. With the growth in livestock, a need is also felt to create effective product supply chains in order to sustain, modulate and promote livestock in particular and agriculture and globalization also in general. Flexible supply chain agreement farming is a mutual integration model that enables companies to have a better control over the yield of farm produce and product modularity. The vertical contracting integration characterizes such a model, except that it excludes the

* Corresponding author

E-mail address: rezaronaldo@stebilampung.ac.id (R. Ronaldo)

(C) 2020 by the authors; licensee Growing Science. doi: $10.5267 /$ j.uscm.2019.8.006

\begin{abstract}
Poultry industry is a key sector in the Indonesian economy, producing and supplying sixty five percent of all animal protein and with ten percent employment share of labor in national
economy. Over the last thirty years, there has been an increase in production of agro food globally. Economists agree that demand of agro product has increased due to population growth, product consumption and the increased income. In Indonesia, poultry production has
not been able to meet the demand which makes it difficult to supply produced chicken to remote areas. Moreover, in Indonesia, the supply chain network of poultry production does not meet the demand of this growing sector Hence, a well-established supply chain system is required in this sector. Large production companies should create a proper supply chain system by integrating poultry product modularity Such an interaction between companies having SCM
skills and poultry suppliers will enhance poultry business performance. This study employed a cross sectional research mode and designed a survey to collect data from poultry production units in Indonesia. Results reveal that due to suppliers' involvement and integrating product modularity make a significant positive effect on poultry business performance. In addition, it which in turn helped poultry producer to develop a better supply chain network. It is recommended that government should make appropriate polices to develop better supply chain networks for the economic growth of country.
\end{abstract}

(O) 2020 by the authors; licensee Growing Science, Canada. 
responsibilities which originate at various levels of production. In exchange for an assured marketplace for his produce, the grower consents to follow a pre-determined chain process of production under the supervision of the purchaser (Ganesh et al., 2000).

Usually the technical support and services come from the purchasers, while the growers contribute in terms of necessary farmland and manpower for production. Mostly agriculture-sector studies are subjective expressing concepts and phenomena of economics. These studies normally address the queries related to general public policies, arrangements related to governance and managing competitiveness of the industry. Similarly, the research on supply chain management is more concerned about market demand as well as about the customers' needs, performance of poultry business, effectiveness, and overall operational efficiency in poultry industry (Lashari et al., 2018).

The main focus of the current research is to develop a framework of SCM raw material to the point of production and finished good delivery to the end user market- which is a very common practice in research related to SCM in agro industrial sector (Wadnerkar \& Dalu, 2018).

This study also examines how to utilize the SCM skills and practices to bring advancement in poultry business supply chain. It also evaluates the poultry supply chain as an agro supply chain, or as a food supply chain with the objective to measure the supply chain business performance of poultry production in Indonesia.

The major question raised in this study is: "Is there any well-established SCM system to assess and evaluate the supply chain of poultry meat business performance in Indonesia through the involvement of poultry product suppliers and by integrating poultry product modularity (Ahmad Shabudin, 2014).

Though all these issues can be handled by integrating supply chain management with poultry business performance, the government of Indonesia is very concerned about taking measures for betterment of supply chain management in poultry business. The government is aware that the involvement of suppliers in poultry business has resulted in its tremendous growth (Waseem-Ul-Hameed et al., 2018). It has also been accepted that by integrating poultry product modularity in poultry business and supply chain management, it is easier to achieve desired growth in this business as well as growth in country's economy (Shamsuddoha, 2011). Any suggested model or framework as given in Figure 1 to integrate them will be helpful in enhancing poultry business performance.

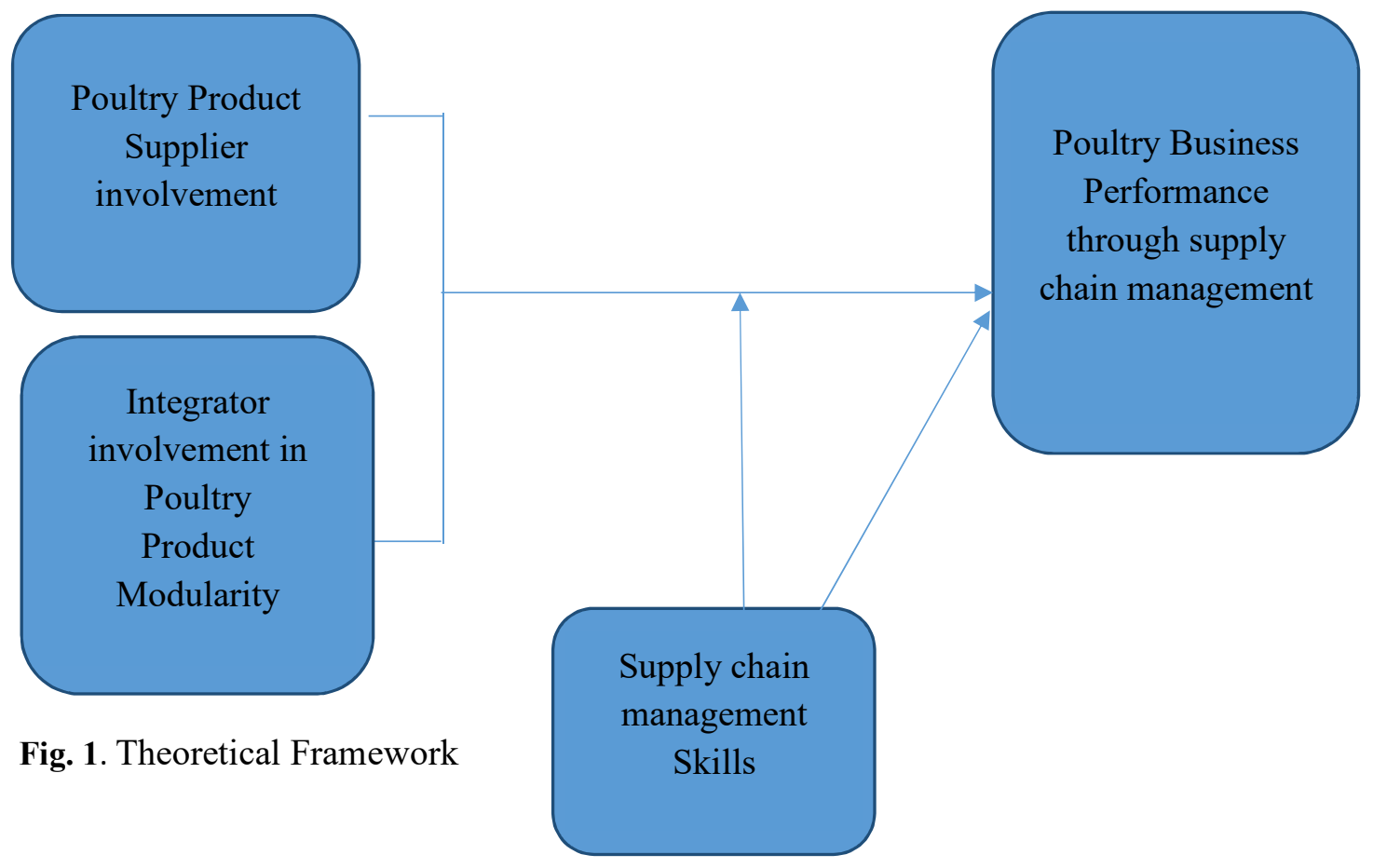


The main aim in this research is to evaluate the poultry business performance indicator through supply chain management in Indonesia. To achieve this core objective some secondary objectives were also framed for this study.

- To examine the role of involvement of supplier in poultry business performance,

- To examine how integration of product modularity in poultry business enhances poultry business performance,

- To examine the mediating role of supply chain management skills in poultry business performance.

This research study will be beneficial for Indonesian government to enhance performance of poultry product business to integrate poultry product modularity and supply chain in this business sector.

\section{Literature Review}

\subsection{Concept of Supply Chain Management (SCM)}

The American Production and Inventory Control Society (APICS, 2008) describes the supply chain management as a connection of chain across supplier-user industries, starting from the point of raw material and ending on the consumption point of the final finished products (Koch et al., 2016). The Council of SCM Professionals (CSCMP) is another leading mainstream association comprising of SCM experts, academicians, and investigators. It defines SCM as planning and management of all activities related to sourcing and procurement, conversion, and logistics management. This includes delivery of a product to the grower beginning with sourcing for the raw material, industrializing and assembling, warehousing and account tracing, entering and managing orders, distribution over all networks, supplying to the producer, and the IT systems. The SCM synchronizes and combines all these activities keeping them on track and engaging all parties. This enables stockholders within the organizational process, the external stakeholders such as suppliers, transporters and companies are indirectly engaged with this business and IT system facilitators to remain integrated in the supply chain (Thatte \& Agrawal, 2017).

\subsection{Poultry Business performance Through Supply Management}

In poultry business, the leading company within the SCM framework prominently arises as the integrator. In SCM the integrator plays a vertical role in integration, being owner of most of the feeding, breeding, slaughtering and provide all processing facilities to smoothen the processes. It also enables to use the latest technology system and maintain stringent hygienic standards in all its processes. It operates together various distribution networks, from supermarkets to distributors and grocery stores. Its products are also delivered directly to eateries. The SCM integrator gains an advantageous edge in the domestic and international markets due to the combined efforts of the whole team. It also highlights the strategic position and the purpose of the company of providing services and customized poultry products to enhance a continual performance of business.

\subsection{Hypothesis Development}

\subsubsection{Poultry Product Supplier involvement:}

Hao and Song (2016) assert that an important route for the success of poultry product can be achieved through involvement of well-designed supply chain network. Yeniyurt et al. (2019) define product supply chain as a direct participation of supplier during the product development processes. It comprises combined product design, process engineering and production operations with major suppliers. It also includes obtaining resources and skills, which the manufacturers do not possess but which are vital for product innovation. While the integrator is encouraged to learn new technology applications, poultry producers can actively influence market product performance in order to organize supply chain network (Clauss \& Spieth, 2016). 
The core competencies of a poultry business are those things that can be performed well by a business and that fulfills following three conditions stipulated by (Qureshi et al., 2017). First, the benefit of customer and it should be available for customer on priority; second, its adoption must be very hard for competitors to copy this model; and third, its use should be generalized in order to get maximum advantage and can be useable with other products in market. Besides, there are many other core competencies too including knowledge about technical and/or subject matters, dependable processes, and close ties with customers and integrators ( $\mathrm{Pu} \& \mathrm{Soh}, 2018)$. Therefore, the involvement of poultry product supplier in a competitive market is crucial. The following hypothesis is therefore proposed from this argument:

$\mathbf{H}_{1}$ : There is a relationship between poultry product supplier involvement and poultry business performance through supply chain management.

\subsubsection{Integrator involvement in Poultry Product Modularity}

The idea of modularity in educational literature was first proposed by Esteve-Altava (2017) when he presented the theme of almost decomposable systems. Magnusson \& Lakemond (2017) state that such decomposable systems are modular when they have a greater level of independence (loose combination). A modular architecture is a unique form of product design in which standardized component boundaries are used to achieve a loose combination in order to achieve the production of a highest level on end items. This was one of the predecessors of mass customization (Vickery et al., 2015). Zhang et al. (2019) coined the term "modularity in use" to refer to this skill and to establish the creation as needed by considering modularity as a design strategy that avoids producing solid inter dependencies among specific components (modules) within the product. The word "module" in this case was defined by Allen et al. (2017) to mean a set of parts that can be detached as a unit from the product without destroying it. Hence modularity can be understood as a systematic idea explaining the extent to which the parts of the system may be taken apart and reorganized into new designs. According to Gutmann et al. (1997), the poultry product modularity consists of a design with sub process that can be put together and analyzed before being integrated. In addition, (Sanchez \& Hang, 2017) stress that it is commonly understood that poultry product modularity integrates the structure blocks that can be merged to produce a relatively high number of product designs.

In previous literature, modularity and standardization are connected with unity and product design. The similarity is apparent in design features and components within the product. Peleh et al. (2019) define standardization as treating the use of common parts as essential to a modular poultry product production design.

Hence, from the above argument, a hypothesis can be proposed:

H2: There is a relationship between Integrator involvement and Poultry Product Modularity in poultry business performance through SCM.

\subsubsection{Supply Chain Management Skills (SCMS)}

In the study of economics, there are many processes which create skills that help to enhance poultry product performance, one of them is supply chain management skills theory. According to Potts and Kastelle (2017) the SCM skills theory it indicates that fruitful attention should be paid for the creation of skills in the area of labor and agro food sector. the theory recognizes that creation of skills characterized in livestock sector at the level of group of agents and whole supply chain system and sustain this organization competencies are greater source for competitive edge in market (Schroeder et al., 2002). The theory also states that a typical skill of poultry industry which offers organizational decision can positively influence the level of supply chain management skills in the livestock sector. There are organizational models that impact the level of supply chain management skills. They are interrelated with the usual organizational processes of poultry farm houses that focus on integrated market creation. Past scholars have written about how to increase supply chain network in food industry 
and discussed the complexities of poultry organizations sector and the growth of SCM analytical in whole network. The results of these studies reveal that poultry industry is under the threat of harsh economic volatility of governments. The greatest challenge for governments is to offer specific consideration to management procedures with regard to poultry production in order to increase efficiency (Suleiman et al., 2018).

In order to maintain the quality of SCM skills, it is important for each production unit to resort to using certain indexes of quantity until they can be applied in the production function (Hamidi, 2017). Hence, supply chain management skills are deemed to be the most efficient mediators for managing the supplier involvement and poultry product modularity in poultry business performance management. Hence, the following assumptions can be stated based on these findings:

H3: There is a relationship between SCM managerial skills and poultry business performance through supply chain management.

H4: SCM skills moderate the relationship between poultry product supplier involvement and poultry business performance through supply chain management.

H5: SCM skills moderate the relationship between involvement of Integrator in Modularity of Poultry Product and poultry business performance through supply chain management.

\section{Research Methodology}

The population of this research was all poultry producers in Indonesia and quantitative analysis method was adopted to measure this study. This study explored the association between variables, like integrator supplier involvement in poultry product modularity, poultry sector growth and the moderating role of SCM skills to manage poultry production supply in Indonesia. Data was collected through survey techniques and descriptive analytical tools were used for analysis. The sample chosen were commercial level poultry producers registered with The Indonesia Feed and Livestock Sector (IFLS) of Indonesia in three provinces. The instrument used for data collection was a questionnaire which consisted of an introduction, the research purpose and questions about variables of the study like integrator involvement for poultry product modularity, supplier involvement, moderating role of SCM skills and characteristics of individual poultry producers and relevant about poultry production.

\subsection{Sampling Method}

The identification of population is the core to select a sample In this study, the sample chosen comprised a group of people and organization which were involved in the poultry production at a commercial level and are responsible to supply them in the final market. The rationale to choose the poultry production segment was because of its highest distribution of chicken and other poultry products in the market (Shabudin, Mohtar, \& Mad Lazim, 2015). The addresses and names of chicken contractors were taken from public authority of Indonesian Feed and Livestock Sector (IFLS). For the measurement of construct a multi item measurement scale for hypothesis tests was adopted which was borrowed from prior researches. A 5-point Likert scale was used for the measurement of questionnaire items which start with (1) as very low and (5) as very high.

\subsection{Data Collection}

Data was mainly collected through Emails. A proper mail was drafted stating the importance of research explaining the objectives of the study. A cover letter was also appended with the mail to enhance the response rate.

\subsection{Sample Size}

The sample size was determined on the recommendations of Comrey \& Lee, 1992 for studies on inferential statistics. As per their recommendations, under fifty (50) sample size was not up to the mark and considered weaker and sample of 100 was weak, sample of 200 respondents was considered 
adequate and sample of 300 respondents was characterized good, five hundred was very good and one thousand would be excellent. Due to limited access to data and unable to cover whole geographical areas, a sample size of 200 respondents was chosen. .

\subsection{Statistical Tool}

For statistical analysis software Smart PLS 3 (SEM) was chosen and deemed ideal for the analysis of the sample size pf this study. The rate of feedback from respondents was too low in this study. Only eighty one (81) valid feedbacks were used to process this data for analysis. According to MacCallum, Browne, and Sugawara (1996) if structural model is complicated then there is no need to make sample size large because "PLS algorithm does not compute all the relationships at the same time." Several other studies have also used PLS with small sample size (Marcoulides \& Saunders, 2006) In fact, PLSSEM has the highest statistical power to analyze the data even when the size of sample is very small. Furthermore, many researches have supported this narrative on smart PLS and confirmed that PLS was good for analysis when sample size is small (Hameed et al., 2018; Hair, Hult, Ringle, Sarstedt, \& Thiele, 2017). Table 1 illustrates the rate of response.

\section{Table 1}

Respondents feedback

\begin{tabular}{lc}
\hline Responses & Rate/ Frequency \\
\hline No of questionnaires Emailed & 200 \\
No of questionnaires received & 94 \\
No of questionnaires' Useable & 81 \\
No of questionnaires excluded not properly filled & 13 \\
Response rate total & $47 \%$ \\
Response rate after entering data & $40.5 \%$ \\
\hline
\end{tabular}

Source: Based on survey data Author's self-estimate

According to Sekaran and Bougie (2003), if data is collected via email then response rate of 30\% is consider sufficient. However, in the current survey response rate noted was $47 \%$ and after excluding the usable questioners, the response rate of $40.5 \%$ was noted, which was sufficient to proceed for data analysis.

\subsection{Measurement Model Assessment}

Model of measurement was analyzed on the basis of smart PLS 3. The Measurement model was assessed and examined for the Cronbach's alpha, composite reliability, factor loading, discriminant validity and average extracted variance. In Fig. 2 and Table 2 results of measurement model are expressed.

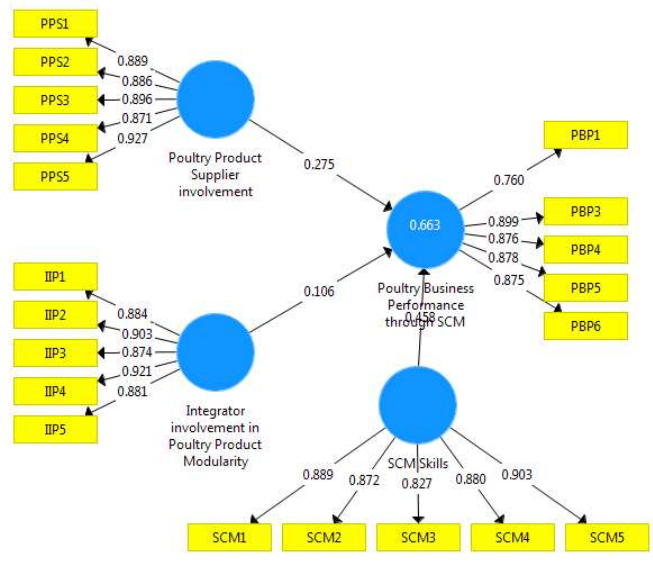

Fig. 2. Measurement Model Assessment 
These figures show the scenario prior to hypothesis testing. It also represents value of $\mathrm{R}^{2}$ and factor loadings of each item.

Table 2

Internal Consistency, Convergent Validity, composite reliability and AVE

\begin{tabular}{|c|c|c|c|c|c|}
\hline Construct & Items & $\begin{array}{l}\text { Factor } \\
\text { loadings }\end{array}$ & $\begin{array}{l}\text { Cronbach's } \\
\text { alpha }\end{array}$ & $\begin{array}{l}\text { Composite } \\
\text { Reliability }\end{array}$ & AVE \\
\hline \multirow[t]{5}{*}{ Poultry business performance through SCM } & PBP1 & .760 & .911 & .914 & .738 \\
\hline & PBP3 & .899 & & & \\
\hline & PBP4 & .876 & & & \\
\hline & PBP5 & .878 & & & \\
\hline & PBP6 & .875 & & & \\
\hline \multirow[t]{5}{*}{ Poultry product supplier involvement } & PPS1 & .889 & .937 & .952 & .799 \\
\hline & PPS2 & .886 & & & \\
\hline & PPS3 & .896 & & & \\
\hline & PPS4 & .871 & & & \\
\hline & PPS5 & .927 & & & \\
\hline \multirow[t]{5}{*}{ Integrator involvement in poultry product modularity } & IIP1 & .884 & .936 & .951 & .797 \\
\hline & IIP2 & .903 & & & \\
\hline & IIP3 & .874 & & & \\
\hline & IIP4 & .921 & & & \\
\hline & IIP5 & .881 & & & \\
\hline \multirow[t]{5}{*}{ Supply chain management skills } & SCM1 & .889 & .923 & .942 & .765 \\
\hline & SCM2 & .872 & & & \\
\hline & SCM3 & .827 & & & \\
\hline & SCM4 & .880 & & & \\
\hline & SCM5 & .903 & & & \\
\hline
\end{tabular}

Source: Based on survey data Author's self-estimate

Table 2 shows factor loading values, Cronbach's Alpha values, Composite Reliability Values and Values of Average Variance extracted. In the results of factor loading only item no 2 of poultry business performance through SCM was found below 0.7 and therefore it was excluded from the results. This study follows the value proposition that if Cronbach's alpha value is more than $0.7(\alpha>0.9)$ it will be considerable. Findings of this study reveal that this value was above 0.9 which is considered excellent. Moreover, if composite reliability is equal to or greater than 0.7 and if AVE value is equal to or more than 0.5 , it is considered to be excellent. In this study, values of AVE and composite reliability are above from required range and also more than the required benchmark. The construct discriminant validity is shown in Table 3.

Table 3

Discriminant Validity

\begin{tabular}{lllll}
\hline Items & IIP & PBP & PPS & SCM Skills \\
\hline IIP & .893 & & & \\
PBP & .771 & .859 & & \\
PPS & .802 & .781 & .894 & .875 \\
SCM Skills & .809 & .801 & .796 & .89 \\
\hline
\end{tabular}

Source: Based on survey data Author's self-estimate

\subsubsection{Structural model assessment}

To achieve the purpose of study, structural model assessment was analyzed after assessing the measurement model. This analysis shows direct and indirect effects of the study. 


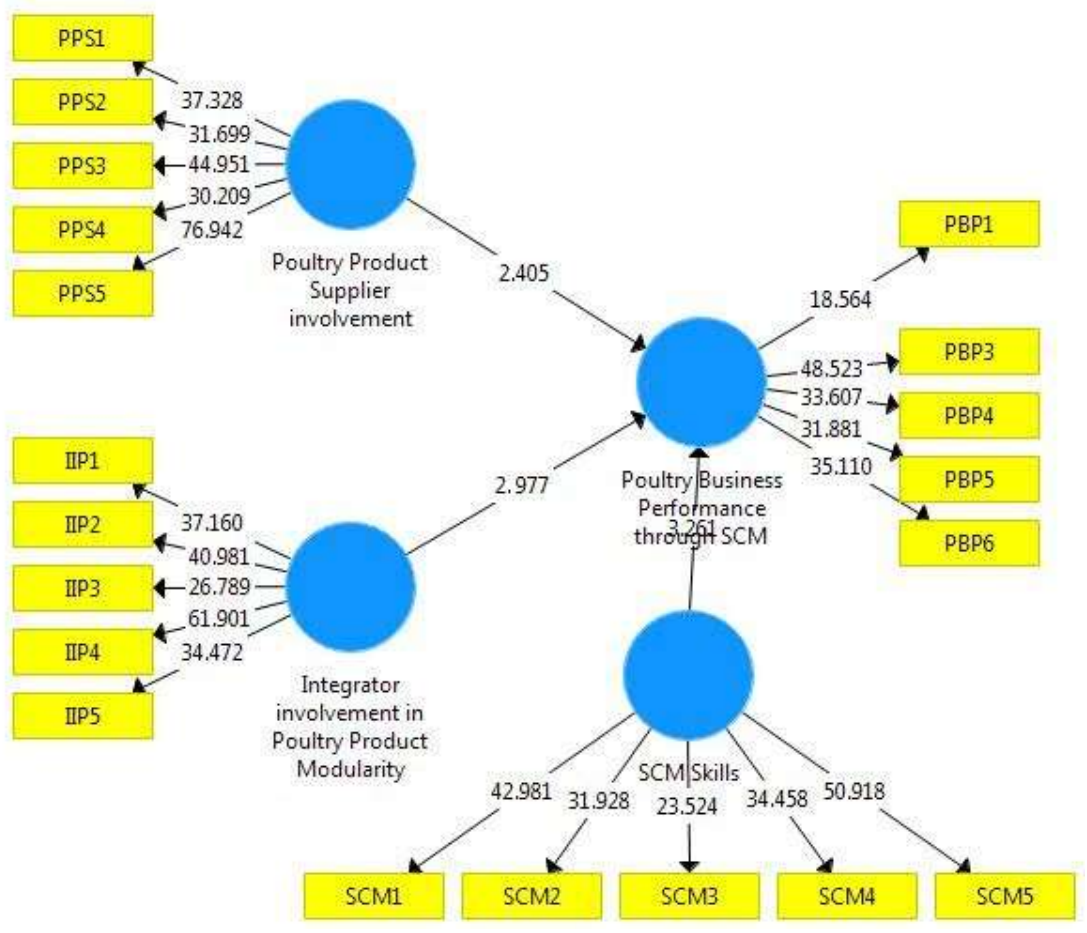

Fig. 3. Structural Model Assessment (Direct Effect).

The structural model shows the results directly and indirectly after testing of hypothesis. Mainly, it shows t- values and path-coefficient which would result in either to accept or to reject the hypotheses. By considering path coefficient hypothesis " $\mathrm{t}$ " value was confirmed. Additionally, $\mathrm{R}$-square $\left(\mathrm{R}^{2}\right)$ and predictive relevance (Q2) were examined. The current study has three (03) direct hypotheses as shown in Fig. 3 and Table 4. All direct hypotheses $(\mathrm{H} 1, \mathrm{H} 2, \mathrm{H} 3)$ were accepted as the t-value was greater than 1.96. Moreover, PLS-SEM bootstrapping was chosen to find out additional effect. It was found that this was the most appropriate tool to analyze data with small sample size. Moreover, by following the suggestions of Hair et al (2014), in order to examine the mediation effect, the procedure of (Preacher \& Hayes, 2008) was followed and the in-direct effect was examined. Therefore, the current study analyzed the effect of SCM skills as a moderator through Smart PLS 3.0 (Henseler et al., 2015) used the bootstrapping technique and reexamined the t-value.

Table 4

Structural Model Assessment (Direct Effect Results and Decision

\begin{tabular}{llcccccc}
\hline Hypothesis & Relationship & $\begin{array}{c}\text { Original } \\
\text { sample(o) }\end{array}$ & $\begin{array}{c}\text { Sample } \\
\text { mean(M) }\end{array}$ & $\begin{array}{c}\text { Standard deviation } \\
\text { (STDEv) }\end{array}$ & $\begin{array}{c}\text { T statistics } \\
(\text { lo/STDEvl) }\end{array}$ & $\begin{array}{c}\text { P } \\
\text { Values }\end{array}$ & Decision \\
\hline $\mathrm{H}_{1}$ & IIP $\rightarrow$ PBP & .106 & .109 & .036 & 2.977 & .002 & Accepted \\
$\mathrm{H}_{2}$ & $\mathrm{PPS} \rightarrow$ PBP & .275 & .269 & .114 & 2.405 & .017 & Accepted \\
$\mathrm{H}_{3}$ & $\mathrm{SCM} \rightarrow$ PBP & .458 & .462 & .14 & 3.261 & .001 & Accepted \\
\hline
\end{tabular}

Source: Based on survey data Author's self-estimate

\section{Discussion and Research Findings}

This study was primarily conducted to explore the key factors of poultry business performance through SCM and to explore the moderating role of supply chain or management skills. Therefore, the effect of 
supplier involvement and integrator of poultry product modularity involvement was examined with moderating role of SCM skills on poultry business performance in Indonesian Poultry industry.

The direct effect of Supplier involvement and integrator involvement in product modularity on poultry business performance shows t-value of $2.103,2.213,2.187$, respectively with value of $\beta$ of.229, 0.309 , and .241 , respectively. It shows a positive impact significantly on poultry business performance through supply chain management. Therefore, the greater is the involvement of supplier and integrator in product modularity in this business, the higher will be overall performance of poultry business. Moreover, the more is the supplier involvement and of the integrator, the more is the performance of poultry business through SCM. According to findings of (Kannan \& Choon Tan, 2006), maximization of supplier involvement and integrating product modularity with poultry business enhances the performance of poultry business performance. Furthermore, when the role of SCM skills with supplier involvement and product modularity were examined, it showed that t-values were 2.187 and 2.103, respectively with $\beta$-values of .241 and 0.229 respectively. These values indicate that the two variables, supplier involvement and integrator involvement in product modularity, had a positive significant effect on SCM skills. The results also reveal a direct and positive relationship between three of these variables, supplier involvement, integrator involvement and SCM skills. This concludes that investment in SCM skills would enhance the acquisition of Poultry business performance.

\section{Conclusion}

The current study has shown strong evidence that supplier involvement and integrator product modularity increased the performance of poultry product business performance in Indonesia. Further, better utilization as well as engagement of maximum level of SCM skills and maximization of supplier involvement also increased the poultry business performance. Moreover, the results also revealed that involvement and collaboration between product modularity integration and maximum productivity from supplier involvement was hardly conceivable without SCM skills. SCM skills are therefore crucial to enhance the poultry business performance. Hence, Supplier involvement and SCM skills prove to be major determinants of Poultry business performance in Indonesian poultry industry.

Additionally, poultry industry also requires a certain level of product modularity integration. SCM skills enhance the supplier involvement which automatically increases poultry business performance. In this study considerable evidence was found on the implication of Supply chain management skills as moderator making a positive impact on supplier involvement and integrator involvement in poultry product modulation and on performance of the poultry business. Moreover, there are many practical considerations of this study which engages supplier involvement of poultry business and also in Indonesian services associated to poultry industry. The outcomes of this study also indicate that actual execution of product modularity integration, boosting of supplier involvement and financing in SCM skills are major reflections for the poultry business performance. Poultry industry should initiate rational measures to exploit their SCM skills by raising the performance of supplier and product integration in poultry business performance enhancing. The potential of poultry industry in halal market takes serious consideration of increasing the current economic growth. Additionally, more financial resources are required in SCM skills to encase the potential of poultry industry's share from the halal market. Thus, development of SCM skills will ultimately boost up the poultry business performance. Future studies to explore the effect of other variables such as intellectual SCM management in poultry industry and Halal food market integration are recommended.

\section{Acknowledgement}

The authors would like to thank the anonymous referees for constructive comments on earlier version of this paper. 


\section{References}

Ahmad Shabudin, A. (2014). Contract farming supply chain relationship and business performance within Malaysian poultry industry. Universiti Utara Malaysia.

Clauss, T., \& Spieth, P. (2016). Treat your suppliers right! Aligning strategic innovation orientation in captive supplier relationships with relational and transactional governance mechanisms. $R \& D$ Management, 46(S3), 1044-1061.

Comrey, A., \& Lee, H. (1992). Interpretation and application of factor analytic results. Comrey AL, Lee HB. A first course in factor analysis, 2, 1992.

Delgado, C., Rosegrant, M., Steinfeld, H., \& Ehui, S. (2020). C. Courbois, C. 1999. The Next Food Revolution. Chapter 14. Livestock to.

Esteve-Altava, B. (2017). In search of morphological modules: a systematic review. Biological Reviews, 92(3), 1332-1347.

Ganesh, J., Arnold, M. J., \& Reynolds, K. E. (2000). Understanding the customer base of service providers: an examination of the differences between switchers and stayers. Journal of marketing, 64(3), 65-87.

Gutmann, D. H., Aylsworth, A., Carey, J. C., Korf, B., Marks, J., Pyeritz, R. E., . . . Viskochil, D. (1997). The diagnostic evaluation and multidisciplinary management of neurofibromatosis 1 and neurofibromatosis 2. Jama, 278(1), 51-57.

Hair, J. F., Hult, G. T. M., Ringle, C. M., Sarstedt, M., \& Thiele, K. O. (2017). Mirror, mirror on the wall: a comparative evaluation of composite-based structural equation modeling methods. Journal of the Academy of Marketing Science, 45(5), 616-632.

Hameed, W. U., Basheer, M. F., Iqbal, J., Anwar, A., \& Ahmad, H. K. (2018). Determinants of Firm's open innovation performance and the role of $\mathrm{R} \& \mathrm{D}$ department: an empirical evidence from Malaysian SME's. Journal of Global Entrepreneurship Research, 8(1), 29.

Hamidi, H. (2017). A model for impact of organizational project benefits management and its impact on end user. Journal of Organizational and End User Computing (JOEUC), 29(1), 51-65.

Hao, S., \& Song, M. (2016). Technology-driven strategy and firm performance: Are strategic capabilities missing links? Journal of Business Research, 69(2), 751-759.

Henseler, J., Ringle, C. M., \& Sarstedt, M. (2015). A new criterion for assessing discriminant validity in variance-based structural equation modeling. Journal of the Academy of Marketing Science, 43(1), 115-135.

Jung, S., \& Simpson, T. W. (2017). New modularity indices for modularity assessment and clustering of product architecture. Journal of Engineering Design, 28(1), 1-22.

Kannan, V. R., \& Choon Tan, K. (2006). Buyer-supplier relationships: The impact of supplier selection and buyer-supplier engagement on relationship and firm performance. International Journal of Physical Distribution \& Logistics Management, 36(10), 755-775.

Koch, C., Nyffeler, N., \& Arnould, Y. (2016). The Dilemmas of Mechatronics Business, Between Customer Demands and Concepts for Product Platforms. Paper presented at the European Conference on Management, Leadership \& Governance.

Lashari, M. H., Memon, A. A., Shah, S. A. A., Nenwani, K., \& Shafqat, F. (2018). IoT Based Poultry Environment Monitoring System. Paper presented at the 2018 IEEE International Conference on Internet of Things and Intelligence System (IOTAIS).

MacCallum, R. C., Browne, M. W., \& Sugawara, H. M. (1996). Power analysis and determination of sample size for covariance structure modeling. Psychological methods, 1(2), 130.

Magnusson, T., \& Lakemond, N. (2017). Evolving schemes of interpretation: investigating the dual role of architectures in new product development. $R \& D$ Management, 47(1), 36-46.

Marcoulides, G. A., \& Saunders, C. (2006). Editor's comments: PLS: a silver bullet? MIS quarterly, $30(2), 3-4$.

McKenzie, K., Murray, A. L., Wilkinson, A., Murray, G. C., Metcalfe, D., O'Donnell, M., \& McCarty, K. (2018). The relations between processing style, autistic-like traits, and emotion recognition in 
individuals with and without Autism Spectrum Disorder. Personality and Individual Differences, 120, 1-6.

Peleh, T., Ike, K. G., Wams, E. J., Lebois, E. P., \& Hengerer, B. (2019). The reverse translation of a quantitative neuropsychiatric framework into preclinical studies: Focus on social interaction and behavior. Neuroscience \& Biobehavioral Reviews.

Potts, J., \& Kastelle, T. (2017). Economics of innovation in Australian agricultural economics and policy. Economic Analysis and Policy, 54, 96-104.

Preacher, K. J., \& Hayes, A. F. (2008). Assessing mediation in communication research. The Sage sourcebook of advanced data analysis methods for communication research, 13-54.

$\mathrm{Pu}, \mathrm{M}$., \& Soh, P.-H. (2018). The role of dual embeddedness and organizational learning in subsidiary development. Asia Pacific Journal of Management, 35(2), 373-397.

Qureshi, M. S., Aziz, N., \& Mian, S. A. (2017). How marketing capabilities shape entrepreneurial firm's performance? Evidence from new technology based firms in turkey. Journal of Global Entrepreneurship Research, 7(1), 15.

Sanchez, R., \& Hang, C. C. (2017). Modularity in new market formation: Lessons for technology and economic policy and competence-based strategic management Mid-Range Management Theory: Competence Perspectives on Modularity and Dynamic Capabilities (pp. 131-165): Emerald Publishing Limited.

Schroeder, R. G., Bates, K. A., \& Junttila, M. A. (2002). A resource-based view of manufacturing strategy and the relationship to manufacturing performance. Strategic management journal, 23(2), 105-117.

Sekaran, U., \& Bougie, R. (2003). Research methods: A skill building approach: New York.

Shabudin, A., Mohtar, S., \& Mad Lazim, H. (2015). Associations between integrator, grower involvement and business performance: Emphasis on validity \& reliability. Management and Organizational Studies.

Shamsuddoha, M. (2011). Applying reverse supply chain in the poultry industry. Paper presented at the CGSB Research Forum.

Suleiman, R., Mahmud, A., Oladimeji, Y., Olanrewaju, T., \& Ojeleye, O. (2018). Effects of SocioEconomic Characteristics on the Profitability of Poultry Production among Poultry Farmers in Kaduna State. Journal of Agricultural Extension, 22(1), 185-195.

Thatte, A., \& Agrawal, V. (2017). Exploring supply chain responsiveness effects on competitive advantage of a firm. Quarterly Review of Business Disciplines, 4(3), 211-228.

Vickery, S. K., Bolumole, Y. A., Castel, M. J., \& Calantone, R. J. (2015). The effects of product modularity on launch speed. International Journal of Production Research, 53(17), 5369-5381.

Wadnerkar, P., \& Dalu, R. (2018). TO STUDY THE PRESENT STATUS OF SUPPLY CHAIN MANAGEMENT IN MEDIUM SCALE AGRO IMPLEMENTS MANUFACTURING INDUSTRIES. Journal of Mechanical and Industrial Engineering Research, 7(2), 1.

Waseem-Ul-Hameed, S. N., Azeem, M., Aljumah, A. I., \& Adeyemi, R. A. (2018). Determinants of elogistic customer satisfaction: A mediating role of information and communication technology (ICT). International Journal of Supply Chain Management, 7(1), 105.

Williams, C., Colovic, A., \& Zhu, J. (2017). Integration-responsiveness, local hires and subsidiary performance amidst turbulence: Insights from a survey of Chinese subsidiaries. Journal of World Business, 52(6), 842-853.

Yeniyurt, S., Wu, F., Kim, D., \& Cavusgil, S. T. (2019). Information technology resources, innovativeness, and supply chain capabilities as drivers of business performance: A retrospective and future research directions. Industrial Marketing Management.

Zhang, M., Guo, H., Huo, B., Zhao, X., \& Huang, J. (2019). Linking supply chain quality integration with mass customization and product modularity. International Journal of Production Economics, 207, 227-235. 
(C) 2020 by the authors; licensee Growing Science, Canada. This is an open access article distributed under the terms and conditions of the Creative Commons Attribution (CC-BY) license (http://creativecommons.org/licenses/by/4.0/). 